\title{
Association of 25-hydroxy vitamin D level with the blood pressure response to a maximum exercise test among professional indoor athletes
}

\author{
Pascal Bauer $^{1}$ [D $\cdot$ Lutz Kraushaar $^{2} \cdot$ Oliver Dörr $^{1} \cdot$ Timm Bauer $^{3} \cdot$ Holger Nef $^{1} \cdot$ Christian W. Hamm $^{1,4} \cdot$ Astrid Most $^{1}$
}

Received: 20 December 2019 / Accepted: 13 June 2020 / Published online: 25 June 2020

(c) The Author(s) 2020

\begin{abstract}
Purpose Low vitamin D levels have been associated with elevated blood pressure (BP) in the general population. However, whether there is an association of vitamin D insufficiency with BP changes during maximum exercise in athletes is currently unclear.

Methods A total of 120 male professional indoor athletes (age $26 \pm 5$ years) were examined. BP was measured at rest and during a graded cycling test. We assessed the BP response (BPR) during maximum exercise and the respective load. BP and BPR (peak-baseline BP) were analysed with respect to $25-\mathrm{OH}$ vitamin D levels, with levels $<30 \mathrm{ng} / \mathrm{mL}$ defining vitamin D insufficiency.

Results 35 athletes were classified as being vitamin D insufficient. BP was not different between sufficient and insufficient vitamin D groups $(122 \pm 10 / 75 \pm 7$ vs. $120 \pm 12 / 77 \pm 9 \mathrm{mmHg})$. At maximum exercise, however, systolic BP (198 \pm 17 vs. $189 \pm 19, p=0.026)$ and the pulse pressure $(118 \pm 18$ vs. $109 \pm 21 \mathrm{mmHg}, p=0.021)$ were higher in the sufficient group; the BPR was not different between groups $(76 \pm 20 / 5 \pm 6$ vs. $69 \pm 22 / 3 \pm 6 \mathrm{mmHg}, p=0.103)$. Athletes with sufficient levels had a higher maximum power output $(3.99 \pm 0.82 \mathrm{vs.} 3.58 \pm 0.78 \mathrm{~W} / \mathrm{kg}, p=0.015)$ and achieved higher workloads $(367 \pm 78 \mathrm{vs}$. $333 \pm 80 \mathrm{~W}, p=0.003$ ). The workload-adjusted BPR (maximum systolic BP/MPO) was not different between athletes with sufficient and insufficient vitamin D levels $(51 \pm 10$ vs. $56 \pm 14 \mathrm{mmHg} \times \mathrm{kg} / \mathrm{W}, p=0.079)$.

Conclusion Athletes with sufficient vitamin D achieved a higher maximum systolic BP and a higher maximum power output. The workload-adjusted BPR was not different between groups, which suggests that this finding reflects a better performance of athletes with sufficient vitamin D.
\end{abstract}

Keywords Exercise test · Professional athletes · Indoor sports · Performance · Vitamin D · Blood pressure response · Hypertension

\begin{tabular}{|c|c|}
\hline \multicolumn{2}{|c|}{ Abbreviations } \\
\hline $\mathrm{BF}$ & Blood pressure \\
\hline $\mathrm{BF}$ & Blood pressure response \\
\hline \multicolumn{2}{|r|}{ Communicated by Massimo Pagani. } \\
\hline$\triangle$ & $\begin{array}{l}\text { Pascal Bauer } \\
\text { pascal.bauer@innere.med.uni-giessen.de }\end{array}$ \\
\hline 1 & $\begin{array}{l}\text { Department of Cardiology and Angiology, Justus- Liebig- } \\
\text { University Giessen, Giessen, Germany }\end{array}$ \\
\hline 2 & Adiphea GmbH, Werbach, Germany \\
\hline 3 & $\begin{array}{l}\text { Department of Cardiology and Intensive Care Medicine, } \\
\text { Sana Clinic Offenbach, Offenbach, Germany }\end{array}$ \\
\hline 4 & $\begin{array}{l}\text { Department of Cardiology, Kerckhoff Clinic GmbH, } \\
\text { Bad Nauheim, Germany }\end{array}$ \\
\hline
\end{tabular}

cBP Central blood pressure

ECG Electrocardiogram

K2EDTA Dipotassium ethylenediamine tetra-acetic acid MPO Maximum power output

SD Standard deviation

VO2max Maximum oxygen uptake

\section{Introduction}

Insufficiency and deficiency of 25-OH vitamin D have been shown to be associated with arterial hypertension (Kunutsor et al. 2013; Wang 2016), increased cardiovascular events, impaired vascular function (Al Mheid et al. 2011), and even cardiovascular mortality (Wang 2016; Anderson et al. 2010; Vimaleswaran et al. 2014). The fact that vitamin D receptors 
are found throughout the cardiovascular system, in particular in smooth muscle cells (Somjen et al. 2005), myocytes, and endothelial cells (Norman 2008), suggests an impact of vitamin D on cardiovascular function. Further, it was found that supplementation of vitamin $\mathrm{D}$ in asymptomatic deficient subjects leads to improved endothelial function and evokes a relaxation of smooth muscle cells (Tarcin et al. 2009). Vitamin D regulated reduction of the activity of the renin-angiotensin-aldosterone system also bespeaks a crucial role of vitamin D in the cardiovascular system (Forman et al. 2010). Taken together, all of this evidence points to mechanisms that potentially mediate a blood pressure-regulating effect of vitamin D.

Healthy individuals with normal blood pressure (BP) at rest but an exaggerated BP response (BPR) during exercise are at higher risk of developing arterial hypertension (Lewis et al. 2008; Holmqvist et al. 2012). In addition, a recent meta-analysis revealed that exercise-induced systolic $\mathrm{BP} \geq 196 \mathrm{mmHg}$ predicted cardiovascular events with a sensitivity of $62 \%$ and a specificity of $75 \%$ (Percuku et al. 2019). The clinical impact of BP response during exercise, however, remains a controversial issue (Kim and Ha 2016; Schultz et al. 2015), and upper reference values for the general population are not well established (Schultz et al. 2013; Gupta et al. 2007; Weiss et al. 2010; Currie et al. 2018). The European Society of Cardiology states in its latest guideline that there is currently no consensus on normal BPR during exercise (Williams et al. 2018). In previous guidelines, a systolic peak BP of $210 \mathrm{mmHg}$ for men and $190 \mathrm{mmHg}$ for women were proposed as diagnostic thresholds for the general population (Mancia et al. 2013). Recommendations for athletes are absent in both guidelines, yet recently published studies proposed different thresholds for defining an exaggerated BPR to exercise (Caselli et al. 2019; Pressler et al. 2018). A higher exercise-induced BP response in athletes was explained as representing a superior exercise performance compared with that of the general population (Caselli et al. 2016). Thus far, there is no consensus about "normal" and "exaggerated" BPR in athletes. In addition, the clinical relevance of "exaggerated" exercise-induced BP in athletes is currently unclear, although a higher risk for development of arterial hypertension in these athletes was suggested (Caselli et al. 2019). In competitive triathletes, an exaggerated BPR to exercise testing was associated with a higher prevalence of myocardial fibrosis (Tahir et al. 2018), raising concerns about potential arrhythmic consequences, including sudden cardiac death (Zorzi et al. 2016).

To date, only a few studies have addressed the BPR to maximum exercise in elite athletes (Pressler et al. 2018; Caselli et al. 2019), and none of these studies reported $25-\mathrm{OH}$ vitamin D status. Vitamin D insufficiency and deficiency is commonly found in athletic populations (Owens et al. 2015; He et al. 2016; Mehran et al. 2016; Maroon et al. 2015). Our group recently discovered a high prevalence of vitamin D insufficiency (25-OH vitamin $\mathrm{D}<30 \mathrm{ng} /$ $\mathrm{mL}$ ) in professional handball athletes in Germany (Bauer et al. 2018). Further, we recently demonstrated that vitamin D-insufficient elite handball athletes displayed a significantly higher peripheral and central BP compared with the values in athletes with sufficient vitamin D levels (Bauer et al. 2019).

Given the acknowledged physiological influences of vitamin D on endothelial and smooth muscle cells (Somjen et al. 2005), the haemodynamic effects of vitamin D insufficiency might be amplified during exercise. As regular exercise, performed at moderate intensity, is a well-known therapeutic tool for lowering BP (Williams et al. 2018), it is obvious that controlling for both vitamin $\mathrm{D}$ and cardiorespiratory fitness status is necessary to gain reliable insights about the impact of vitamin D on BP at rest and the BPR to exercise.

Therefore, this study was undertaken to evaluate the association between 25-OH vitamin D levels, brachial BP at rest, and the BPR to a maximum exercise test in elite indoor athletes. Both handball and ice hockey, with their many interval sprints, are team sports that expose athletes to a high haemodynamic stress. Both were classified as a sport with a high dynamic component (>75\% VO2max) and a moderate static component (10-20\%) (Levine et al. 2015). In addition, both are indoor sports with a higher risk of vitamin D insufficiency compared to outdoor sports (Krzywanski et al. 2016).

\section{Materials and methods}

The study was carried out at the university hospital in Giessen, Germany, which is located near $50^{\circ} \mathrm{N}$ latitude. It was conducted as a cross-sectional study of professional athletes during the routine pre-season medical monitoring program of the first German handball division and the second German ice hockey division. Data were collected in the second half of July in the years 2015-2018. Athletes were studied during the summer, when 25-OH vitamin D levels are expected to have reached their peak (Morton et al. 2012; Krzywanski et al. 2016).

The following criteria for serum 25-OH vitamin D concentrations were chosen according to recently published studies and recommendations (Holick et al. 2011, 2012; Pludowski et al. 2013; Priemel et al. 2010): values $<30 \mathrm{ng} /$ $\mathrm{mL}$ were defined as insufficient and values $\geq 30 \mathrm{ng} / \mathrm{mL}$ were defined as sufficient $25-\mathrm{OH}$ vitamin D levels.

The examination took place at noon between 12:00 and 14:00 o'clock and was scheduled in the 1 st week of the new season after a 6 -week competition-free interval. The last time athletes had trained was $36 \mathrm{~h}$ prior to the study beginning; the last meal was breakfast approximately $3 \mathrm{~h}$ before the investigation. There was no restriction of caffeine 
intake provided. Thus, alcohol consumption was prohibited the two days prior to the study beginning. The day before the examination was filled with commercial dates without physical effort.

\section{Study population}

The participants were 120 healthy, injury-free professional handball and ice hockey athletes of varying nationalities. All athletes included were Caucasians with white skin and none of them was a regular sunbed user. None took vitamin D supplements or other multivitamin supplements. All individuals were subjected to a physical examination, 12-lead electrocardiogram (ECG), cardiopulmonary exercise test, and blood testing. Age, height, weight, body mass index, serum $25-\mathrm{OH}$ vitamin $\mathrm{D}$, calcium, magnesium and parathyroid hormone levels were determined. Body surface area was calculated using the formula of DuBois (Du Bois and Du Bois 1989). Maximum workload, maximum power output, heart rate at rest, brachial $\mathrm{BP}$ at rest, maximum heart rate, and maximum BP were assessed. Players then were divided into groups according to vitamin D levels as described above, and statistical analyses were performed.

\section{Laboratory testing}

Blood samples were drawn from an antecubital vein in a sitting position. Blood samples for plasma analyses were collected into two $7.5 \mathrm{~mL} \mathrm{~S}$-Monovette ${ }^{\circledR}$ tubes (Sarstedt AG \& Co. KG, Germany), one containing lithium heparin. An additional $2.7 \mathrm{~mL}$ sample, with dipotassium ethylenediamine tetra-acetic acid (K2EDTA) as anticoagulant, was acquired (Sarstedt AG \& Co. KG, Germany). Automated analysis was carried out within 30 min of blood draw. Serum 25-OH vitamin D concentrations were determined with a Liaison diagnostic system (DiaSorin, Stillwater, MN, USA) by chemiluminescent immunoassay. The range of detection is $4-150 \mathrm{ng} / \mathrm{mL}$ with a precision of $5.0 \% \mathrm{CV}$ and an accuracy $\mathrm{SD}$ of 1.2. Parathyroid hormone was analysed using an electrochemiluminescent immunoassay (Elecsys PTH $(1-84)^{\circledR}$, Roche Diagnostics, Germany), which measures the circulating active parathyroid hormone. The range of detection is $5.5-2300 \mathrm{pg} / \mathrm{mL}$ with a precision range of $2.5-3.4 \%$ CV. Furthermore, calcium levels, a complete blood cell count, and a basic metabolic panel including electrolytes were assessed and analysed by a Modular Analytics E 170 module (Roche Diagnostics, Mannheim, Germany).

All participants received a clear explanation of the study and provided their written informed consent. The local ethics committee of the University of Giessen approved the study protocol. The study meets current ethical standards (Harriss et al. 2017).

\section{Blood pressure measurements at rest before the exercise testing}

Resting brachial BP was measured before the exercise testing using a validated automatic device based on a standard sphygmomanometer technique (Boso clinicus, Bosch + Sohn GmbH \& Co. KG, Germany). The cuff used for measurement was adjusted to the individual's arm circumference. Measurements were performed by a trained research associate on both arms in a sitting position after a resting period of $5 \mathrm{~min}$ and repeated after $2 \mathrm{~min}$. The average BP for each arm was calculated and the highest value was used for statistical analyses. Athletes with a resting $\mathrm{BP}>140 \mathrm{mmHg}$ systolic or $>90 \mathrm{mmHg}$ diastolic were excluded from the study.

\section{Exercise testing and assessment of maximum blood pressure}

Athletes underwent a progressive maximal cycling ergometer test with concurrent automatic brachial BP measurement and ECG recording (Schiller $\mathrm{AG}^{\circledR}$, Switzerland). The exercise test protocol started with a load level of $100 \mathrm{~W}$ after a 2-min warm-up period that was conducted with $50 \mathrm{~W}$. Loads were increased by $50 \mathrm{~W}$ every 2 min until exhaustion, which was defined as the participant's inability to maintain the load for $2 \mathrm{~min}$. Next, the load was decreased to $25 \mathrm{~W}$ for $3 \mathrm{~min}$ of active recovery, followed by a 2-min cool-down period at rest. The test concluded with a final ECG recording and a brachial BP measurement. BP (systolic and diastolic) was measured once a minute during test and recovery periods, including at the maximum workload, immediately after the maximum workload, immediately after the end of the test, and after 5 min of recovery. Heart rate was measured with continuous ECG recording throughout the test and recovery periods. We assessed the absolute maximum power output (MPO) of the athletes as well as the MPO adjusted to individual body weight. Other measurements included maximum heart rate and heart rate at rest and $5 \mathrm{~min}$ after the exercise test.

Increases in systolic and diastolic BP were calculated from peak and baseline (resting) values and determined as blood pressure response (BPR). Further, the workloadadjusted BPR was calculated via maximum systolic BP/ MPO. Pulse pressure was calculated as systolic_-diastolic $\mathrm{BP}$ at rest and at maximum exercise conditions. In addition, mean $\mathrm{BP}$ was determined as: diastolic $\mathrm{BP}+$ (systolic BPdiastolic BP)/3. 


\section{Statistical analysis}

Descriptive analyses were carried out on all study variables for the total sample. Further, descriptive statistics were used on all study variables by $25-\mathrm{OH}$ vitamin D status (with $<30 \mathrm{ng} / \mathrm{mL}$ classified as "insufficient" and $\geq 30 \mathrm{ng} / \mathrm{mL}$ regarded as "sufficient"). All data are presented as mean \pm standard deviation (SD). The Shapiro-Wilk test was used to determine normal distribution. In case of skewed distribution of the data, all analyses were performed on normalized data. Between-group comparisons (insufficient vs. sufficient $25-\mathrm{OH}$ vitamin D levels) were made using independent sample $t$ tests. Bivariate relations were analysed using Pearson's product-moment correlation coefficient. Statistical significance was set at $p<0.05$ (two-tailed) for all measurements. All statistical analyses were performed using the statistical software SPSS 25.0 for Mac (Statistical Package for the Social Sciences, Chicago, IL, USA).

\section{Results}

\section{Cohort characteristics}

The 120 professional handball and ice hockey athletes (mean age of $25.8 \pm 5.2$ year) included in the study were experienced athletes and had participated in professional training for $9.6 \pm 5$ year with a current mean training time of $17.5 \pm 3.0 \mathrm{~h}$ per week. The height was $189.9 \pm 7.2 \mathrm{~cm}$ and the mean weight was $92.9 \pm 10.6 \mathrm{~kg}$, resulting in mean body mass index of $25.7 \pm 1.85 \mathrm{~kg} / \mathrm{m}^{2}$ (Table 1 ).

The mean 25-OH vitamin D level of the 120 athletes was $37 \pm 11.9 \mathrm{ng} / \mathrm{mL}$. Eighty-five athletes (71\%) displayed sufficient vitamin D levels of $\geq 30 \mathrm{ng} / \mathrm{mL}$ and $35(29 \%)$ were found to be vitamin D insufficient $(<30 \mathrm{ng} / \mathrm{mL})$. There were no significant between-group differences in age and characteristics. As expected, the $25-\mathrm{OH}$ vitamin D levels between the sufficient and insufficient groups $(42.3 \pm 8.9 \mathrm{ng} / \mathrm{mL}$ vs. $22.95 \pm 5.1 \mathrm{ng} / \mathrm{mL})$ were different

Table 1 Characteristics of all 120 professional indoor athletes

\begin{tabular}{lrl}
\hline & Mean & SD \\
\hline Age (years) & 25.8 & 5.2 \\
Height $(\mathrm{cm})$ & 189.8 & 7.2 \\
Weight $(\mathrm{kg})$ & 92.9 & 10.6 \\
Body mass index $\left(\mathrm{kg} / \mathrm{m}^{2}\right)$ & 25.7 & 1.85 \\
History of training $($ years $)$ & 9.6 & 5 \\
Training per week $(\mathrm{h})$ & 17.5 & 3 \\
\hline
\end{tabular}

$(p<0.001)$. Table 2 shows the between-group comparison for all parameters measured.

\section{5-OH vitamin D and resting blood pressure}

The mean systolic/diastolic BP in all 120 athletes was $121 \pm 10 / 75 \pm 7 \mathrm{mmHg}$. The level of $25-\mathrm{OH}$ vitamin $\mathrm{D}$ was positively correlated with systolic BP $\left(r^{2}=0.186, p=0.045\right)$, whereas 25-OH vitamin D level and diastolic BP were not correlated $\left(r^{2}=-0.10, p=0.28\right)$. Further, there was a positive correlation of $25-\mathrm{OH}$ vitamin $\mathrm{D}$ level and pulse pressure at rest $\left(r^{2}=0.209, p=0.024\right)$. None of the other measured BP parameters correlated with the $25-\mathrm{OH}$ vitamin D status (Table 3).

There were no differences in resting systolic and diastolic BP, pulse pressure, and mean BP between athletes with insufficient and sufficient 25-OH vitamin D levels. Detailed data are given in Table 2.

\section{5-OH vitamin $D$ and blood pressure response during maximum exercise}

The mean maximum $B P$ in all athletes was $193 \pm 21 / 80 \pm 7 \mathrm{mmHg}$, with a mean systolic BP increase of $72 \pm 22 \mathrm{mmHg}$ and a mean diastolic BP increase of $4 \pm 6 \mathrm{mmHg}$. The maximum pulse pressure was $113 \pm 18 \mathrm{mmHg}$.

Athletes with sufficient $25-\mathrm{OH}$ vitamin D levels had a higher maximum systolic BP compared with those with insufficient levels $(198 \pm 17$ vs. $189 \pm 19, p=0.026)$. In addition, the maximum pulse pressure $(118 \pm 18 \mathrm{vs}$. $109 \pm 21 \mathrm{mmHg}, p=0.021$ ) was higher in athletes with sufficient $25-\mathrm{OH}$ vitamin D levels, whereas the individual BPR was not different between groups $(76 \pm 20 / 5 \pm 6$ vs. $69 \pm 22 / 3 \pm 6 \mathrm{mmHg}, p=0.103)$. Detailed data are given in Table 2. In the total sample, $25-\mathrm{OH}$ vitamin $\mathrm{D}$ levels did not correlate with any of the exercise-induced changes in BP (Table 3).

\section{5-OH vitamin D and performance}

All athletes completed the maximum exercise test until exhaustion and a maximum heart rate above the calculated individual $85 \%$ threshold (of individually calculated maximum heart rate). The mean maximum heart rate in all athletes was $184 \pm 8 \mathrm{bpm}$ and the mean workload was $349 \pm 85 \mathrm{~W}$ with a corresponding maximum power output (MPO) of $3.77 \pm 0.85 \mathrm{~W} / \mathrm{kg}$. The workload-adjusted BPR, calculated via maximum systolic BP/MPO, was $53.5 \pm 12 \mathrm{mmHg} \times \mathrm{kg} / \mathrm{W}$. Levels of $25-\mathrm{OH}$ vitamin D correlated positively with maximum workload $\left(r^{2}=0.373\right.$, $p<0.001)$ as well as maximum power output $\left(r^{2}=0.327\right.$, $p<0.001)$, whereas $25-\mathrm{OH}$ vitamin $\mathrm{D}$ levels and the 
Table 2 Comparison of the different characteristics according to $25-\mathrm{OH}$ vitamin $\mathrm{D}$ levels

\begin{tabular}{|c|c|c|c|c|c|}
\hline & \multicolumn{4}{|c|}{$25-\mathrm{OH}$ vitamin D levels } & \multirow[t]{4}{*}{$p$ value } \\
\hline & \multirow{2}{*}{\multicolumn{2}{|c|}{$\begin{array}{l}\geq 30 \mathrm{ng} / \mathrm{mL} \\
n=85\end{array}$}} & \multirow{2}{*}{\multicolumn{2}{|c|}{$\begin{array}{l}<30 \mathrm{ng} / \mathrm{mL} \\
n=35\end{array}$}} & \\
\hline & & & & & \\
\hline & Mean & SD & Mean & SD & \\
\hline $25-\mathrm{OH}$ vitamin $\mathrm{D}(\mathrm{ng} / \mathrm{mL})$ & 42.3 & 8.9 & 22.95 & 5.1 & $<0.001$ \\
\hline Age (years) & 25.5 & 4.8 & 27.5 & 5.8 & 0.063 \\
\hline Weight (kg) & 92.5 & 10.5 & 94 & 11 & 0.505 \\
\hline Height $(\mathrm{cm})$ & 189.6 & 7.0 & 190 & 8.1 & 0.661 \\
\hline BMI $\left(\mathrm{kg} / \mathrm{m}^{2}\right)$ & 25.7 & 1.9 & 25.9 & 1.5 & 0.611 \\
\hline Body surface area $\left(\mathrm{m}^{2}\right)$ & 2.2 & 0.15 & 2.22 & 0.17 & 0.532 \\
\hline Heart rate at rest (bpm) & 58.4 & 10.5 & 59.1 & 9.4 & 0.748 \\
\hline Brachial systolic blood pressure (mmHg) & 122.1 & 10 & 120 & 11.6 & 0.333 \\
\hline Brachial diastolic blood pressure (mmHg) & 75.1 & 7.4 & 76.8 & 8.6 & 0.362 \\
\hline Mean brachial blood pressure $(\mathrm{mmHg})$ & 91 & 6.3 & 90.7 & 6.5 & 0.862 \\
\hline Brachial pulse pressure $(\mathrm{mmHg})$ & 47 & 11 & 43.5 & 13.3 & 0.152 \\
\hline Maximum heart rate (bpm) & 184 & 8.4 & 183.7 & 7.2 & 0.862 \\
\hline Maximum systolic brachial blood pressure $(\mathrm{mmHg})$ & 197.8 & 17.5 & 189.3 & 19.4 & $\mathbf{0 . 0 2 6}$ \\
\hline Mean maximum brachial blood pressure (mmHg) & 116.7 & 8 & 119.1 & 8.2 & 0.169 \\
\hline Increase from resting systolic blood pressure $(\mathrm{mmHg})$ & 75.7 & 20 & 69.3 & 21.6 & 0.103 \\
\hline Brachial pulse pressure exercise $(\mathrm{mmHg})$ & 118 & 18 & 108.9 & 20.8 & $\mathbf{0 . 0 2 1}$ \\
\hline Maximum diastolic brachial blood pressure $(\mathrm{mmHg})$ & 79.7 & 7.4 & 80.4 & 7.3 & 0.651 \\
\hline Increase from resting diastolic blood pressure $(\mathrm{mmHg})$ & 4.6 & 5.7 & 3.4 & 6.3 & 0.621 \\
\hline Maximum work load (W) & 367.2 & 78.4 & 332.8 & 79.9 & $\mathbf{0 . 0 3 9}$ \\
\hline Maximum power output (MPO) (W/kg) & 3.99 & 0.82 & 3.58 & 0.78 & $\mathbf{0 . 0 1 5}$ \\
\hline Max. systolic blood pressure/MPO $(\mathrm{mmHg} \times \mathrm{kg} / \mathrm{W})$ & 51.3 & 10.2 & 55.5 & 14.1 & 0.079 \\
\hline Parathyroid hormone (pg/mL) & 31.2 & 17.5 & 42.3 & 17.5 & 0.003 \\
\hline Calcium (mmol/L) & 2.38 & 0.09 & 2.34 & 0.14 & 0.142 \\
\hline Magnesium (mmol/L) & 0.82 & 0.05 & 0.82 & 0.06 & 0.713 \\
\hline Hemoglobin (g/dL) & 14.9 & 1 & 15.1 & 0.85 & 0.402 \\
\hline Hematocrit (Vol\%) & 42.7 & 2.4 & 42.9 & 2.2 & 0.699 \\
\hline
\end{tabular}

Bold text signifies significant differences. Values are given as means \pm standard deviation (SD) workload-adjusted maximum systolic BP $\left(r^{2}=-0.222\right.$, $p=0.015)$ were negatively correlated. All other exerciseinduced BP measurements did not correlate with $25-\mathrm{OH}$ vitamin D levels (Table 3 ).

As shown in Table 2, athletes with sufficient vitamin D levels had a higher maximum power output and achieved higher workloads than those with insufficient levels. The workload-adjusted BPR was not different between vitamin D-sufficient and -insufficient athletes. Maximum heart rate was also not different between the groups.

Linear regression analyses revealed that a higher level of 25 - vitamin $\mathrm{D}(p<0.001)$ is a statistically significant predictor of a higher maximum output $\left(r^{2}=0.123\right.$, corrected $r^{2}=0.115, p<0.001, \mathrm{~F}(1120)=16$, Durbin-Watson statistic $2.123)$ and of a higher maximum workload $\left(r^{2}=0.126\right.$, corrected $r^{2}=0.118, p<0.001, \mathrm{~F}(1120)=16.5$, Durbin-Watson statistic 2.065). Thus, 25- OH vitamin D levels were not able to predict the workload-adjusted BPR $\left(r^{2}=0.078\right.$, corrected $r^{2}=0.070, p=0.12, \mathrm{~F}(1120)=92.3$, Durbin-Watson statistic $1.23)$.

\section{5-OH vitamin D and blood parameters}

Mean parathyroid hormone levels were $34 \pm 18 \mathrm{ng} / \mathrm{mL}$, calcium levels were $2.37 \pm 0.11 \mathrm{mmol} / \mathrm{L}$, and magnesium levels were $0.82 \pm 0.05 \mathrm{mmol} / \mathrm{L}$ for all athletes. Mean haemoglobin levels were $15 \pm 0.89 \mathrm{~g} / \mathrm{dL}$ and the mean haematocrit was $42.8 \pm 2.24 \%$. We found a negative correlation of $25-\mathrm{OH}$ vitamin $\mathrm{D}$ with parathyroid hormone $\left(r^{2}=-0.330\right.$, $p<0.001)$ and a positive correlation with calcium levels $\left(r^{2}=0.229, p=0.013\right)$. The other parameters tested did not correlate with the $25-\mathrm{OH}$ vitamin D status (Table 3 ).

Athletes with insufficient 25-OH vitamin D levels displayed higher parathyroid hormone levels compared with athletes with sufficient vitamin D $(42.3 \pm 17.5 \mathrm{vs}$. $31.2 \pm 17.5 \mathrm{ng} / \mathrm{mL}, p=0.003)$. The other measured blood 
Table 3 Spearman correlation coefficients for each variable for 120 athletes

\begin{tabular}{|c|c|c|}
\hline Variable & $\begin{array}{l}\text { Correlation with } \\
\text { 25-OH Vitamin D } \\
\text { Concentration }\end{array}$ & $p$ value \\
\hline Age & -0.072 & 0.439 \\
\hline Weight & -0.011 & 0.90 \\
\hline Height & -0.052 & 0.577 \\
\hline BMI & 0.049 & 0.594 \\
\hline History of training & -0.032 & 0.733 \\
\hline Training per week & 0.049 & 0.599 \\
\hline Resting heart rate & 0.012 & 0.905 \\
\hline Systolic blood pressure & 0.186 & 0.045 \\
\hline Diastolic blood pressure & -0.101 & 0.280 \\
\hline Pulse pressure at rest & 0.209 & 0.024 \\
\hline Mean brachial blood pressure & 0.014 & 0.881 \\
\hline Maximum heart rate & 0.081 & 0.387 \\
\hline Maximum systolic blood pressure & 0.078 & 0.401 \\
\hline Maximum diastolic blood pressure & 0.010 & 0.915 \\
\hline Pulse pressure exercise & 0.095 & 0.308 \\
\hline Mean blood pressure exercise & 0.071 & 0.527 \\
\hline Increase from resting systolic BP & -0.026 & 0.777 \\
\hline Increase from resting diastolic $\mathrm{BP}$ & 0.113 & 0.223 \\
\hline Increase from resting mean $\mathrm{BP}$ & 0.059 & 0.527 \\
\hline Maximum workload & 0.373 & $<0.001$ \\
\hline Maximum power output (MPO) & 0.327 & $<0.001$ \\
\hline Maximum systolic BP/ MPO & -0.222 & 0.015 \\
\hline Parathyroid hormone & -0.330 & $<0.001$ \\
\hline Calcium & 0.229 & 0.013 \\
\hline Magnesium & -0.077 & 0.422 \\
\hline Hemoglobin & 0.067 & 0.477 \\
\hline Hematocrit & 0.014 & 0.877 \\
\hline
\end{tabular}

Bold text signifies a significant correlation

parameters did not show differences between the two groups (Table 2).

\section{Discussion}

To the best of our knowledge, our study is the first to investigate the blood pressure response to a standardized maximum exercise test in professional indoor athletes in Germany and its correlation with $25-\mathrm{OH}$ vitamin D status. Our main findings are that athletes with sufficient vitamin D levels displayed a higher maximum systolic BP and maximum pulse pressure during exercise compared with athletes with insufficient vitamin D levels. Further, the achieved maximum workload and MPO were higher in athletes with sufficient vitamin D levels. The BP increases during exercise (BPR) and the workload-adjusted BPR were not different between the sufficient and insufficient groups, however, indicating that the higher maximum systolic BP in sufficient athletes was caused by the better MPO. This assumption is underpinned by the lack of a correlation of vitamin D levels with both the maximum systolic BP and the BPR. Further, 25-OH vitamin D levels predicted maximum workload and MPO, but not the workload-indexed BPR.

These findings were surprising, since we hypothesized that athletes with insufficient vitamin D levels would display both a higher BP at rest and a higher BPR to a maximum exercise test compared with athletes with sufficient vitamin $\mathrm{D}$ levels. These assumptions were based on our own recently published research results in which we demonstrated that vitamin D-insufficient elite handball athletes displayed a higher peripheral and central BP than those with sufficient vitamin D levels (Bauer et al. 2019). Thus, contrary to our hypothesis, the current study showed that vitamin D levels were not associated with the BPR and the maximum BP during a maximum exercise. Athletes with sufficient vitamin D levels even had a higher maximum systolic BP than insufficient athletes, which was explained by the better performance of vitamin D-sufficient athletes.

Interestingly, the detected maximum systolic BP of our professional indoor athletes $(193 \pm 21 \mathrm{mmHg})$ was lower than that reported by Pressler et al. (Pressler et al. 2018), who found a mean maximum BP of $204 \pm 22 \mathrm{mmHg}$ in their male professional athletes. Accordingly, the mean increase from resting systolic BP was lower in our cohort than in theirs $(72 \pm 21$ vs. $80 \pm 20 \mathrm{mmHg}$ ), and the maximum diastolic BP was slightly higher in our cohort $(80 \pm 7$ vs. $77 \pm 9 \mathrm{mmHg})$ both in the total cohort and in the vitamin D-sufficient group. The study of Pressler at el. seems to be the most appropriate study to compare with ours, since their male cohort was of similar age and displayed a similar maximum heart rate (our study $184 \pm 8$ vs. Pressler et al. $186 \pm 12 \mathrm{bpm}$ ) and a comparable MPO $(3.77 \pm 0.85$ vs. $4.15 \pm 0.61 \mathrm{~W} / \mathrm{kg})$. In addition, resting heart rate $(59 \pm 10$ vs. $60 \pm 11 \mathrm{bpm})$ and resting $\mathrm{BP}$ $(122 \pm 10 / 75 \pm 7$ vs. $124 \pm 12 / 77 \pm 7 \mathrm{mmHg})$ were comparable in the two study populations. Unfortunately, the lack of assessment of vitamin D levels in the report by Pressler et al. (Pressler et al. 2018) limits the comparison with our own results.

Another current study by Caselli et al. addressing the BPR to a maximum exercise test in Olympic athletes reported a maximum BP of $190 \pm 20 / 75 \pm 8 \mathrm{mmHg}$ (Caselli et al. 2016), which is lower than the value we measured. Athletes performing "mixed exercise" demonstrated the highest resting BP in this study (Caselli et al. 2016), which is in line with other publications (Berge et al. 2015; Pressler et al. 2018; Hedman et al. 2019b). Further, male athletes have been shown to display a higher resting BP than females (Hedman et al. 2019b; Pressler et al. 2018; Berge et al. 2015). Our cohort, consisting of male handball and ice hockey players 
can also be considered "mixed exercise" athletes. Unfortunately, the data presented by Caselli et al. for mixed sports are not divided by gender, which limits comparison. The maximum workload in this study (Caselli et al. 2016) was significantly lower compared to that of our group $(268 \pm 53$ vs. $349 \pm 85 \mathrm{~W}$ ) and, in addition, the maximum heart rate was significantly lower (166 \pm 10 vs. $184 \pm 8 \mathrm{bpm})$. The mean age of $25 \pm 6$ years and the surprisingly low maximum heart rate raises the question whether the accomplished exercise test can be really considered to be a maximum exercise test. Further, lack of assessment of 25-OH vitamin D precludes correlation with vitamin D status and thus limits the comparison with our results.

Only a few studies have addressed the association of 25-OH vitamin D and BPR with exercise (Zaleski et al. 2019; Babur Guler et al. 2016). None, to the best of our knowledge, have examined professional athletes, a population that has been repeatedly reported to be vitamin D insufficient (Bauer et al. 2018; Owens et al. 2018, 2015). In 417 healthy adults (mean age 44), Zaleski et al. (Zaleski et al. 2019) reported that they found no difference in the BPR to a maximal exercise test and in the maximum BP between probands with insufficient and those with sufficient $25-\mathrm{OH}$ vitamin D concentrations. Only $52 \%$ of the participants displayed normal resting BP, however, and $22.5 \%$ were considered to have established hypertension. Further, the cohort age was given as 20-76 years, data were not stratified by sex, and $>50 \%$ of the participants were females, who display a lower BPR than males (Zaleski et al. 2019). Therefore, these results cannot be meaningfully compared with the findings of our study. This previous study, however, was the first to examine the association of vitamin D levels with the BPR to exercise in a healthy population. Interestingly, the reported maximum BP in this investigation (Zaleski et al. 2019) was considerably lower than in our study and the studies of Caselli et al. (Caselli et al. 2016) and Pressler et al. (Pressler et al. 2018). This finding might be explained by the lower performance of the participants (VO2 max. $34 \mathrm{~mL} /$ $\mathrm{kg} \times \mathrm{min}$ ), as a normal, healthy population was examined instead of athletes (Zaleski et al. 2019).

In our study, we identified a highly significant correlation of vitamin D levels and MPO. The influence of vitamin D on physical performance levels of male professional athletes has been described in several studies (Hamilton et al. 2014; Ksiazek et al. 2016), which can be explained via both its musculoskeletal and cardiovascular effects (Cannell et al. 2009; Owens et al. 2015; Wang 2016; Allison et al. 2015); however, the influence of vitamin D on the BPR to exercise was not examined in athletes thus far. The higher maximum BP that we measured in athletes with sufficient $25-\mathrm{OH}$ vitamin $\mathrm{D}$ levels might be explained by a higher performance. It is known that higher exercise performance correlates with a higher BPR and higher maximum BP in athletes. Therefore, the workload adjustment in the BPR to exercise was proposed to identify athletes with an "exaggerated" BPR instead of using absolute cut-off values (Hedman et al. 2019a). Several mechanisms have been discussed to contribute to the excessive increase in $\mathrm{BP}$ during exercise, including aortic distensibility (Roman et al. 2007; Thijssen et al. 2016), endothelial dysfunction (Tzemos et al. 2009), and increased activation of the renin-angiotensin-aldosterone system (Schultz et al. 2013). Interestingly, all of these modifiers of the BPR to exercise are influenced by $25-\mathrm{OH}$ vitamin D (Norman 2008; Tarcin et al. 2009; Christakos et al. 2013).

We could not detect correlations of vitamin D levels with BP changes under exercise conditions. This might be explained by the excellent fitness of our professional athletes, since it is possible that vitamin D and physical fitness differentially affect the cardiovascular system and the BPR to exercise, with measurable differences only in individuals who cannot compensate for the deleterious effects of vitamin D insufficiency (Norman 2008; Tzemos et al. 2009). Today, the ability to examine vascular function and central haemodynamic parameters including central BP (cBP) via non-invasive tools might offer new opportunities to reveal the influence of 25-OH vitamin D on BP and the BPR to exercise in an athletic population (Bauer et al. 2019). cBP is determined by the complex interaction between aortic compliance, elasticity and the resistance arteries' ability to channel blood flow in accordance with tissue needs (Stephen Hedley and Phelan 2017). Hence, cBP is superior to brachial blood pressure in identifying changes in vascular functional parameters (Hodson et al. 2016) and cardiovascular risk (Williams et al. 2006; Roman et al. 2007; Cheng et al. 2013; Fan et al. 2016; Herbert et al. 2014). Particularly in young men, central diastolic BP, but not peripheral systolic pressure, is a predictor of cardiovascular risk (Wilkinson et al. 2001). Therefore, further studies that investigate the impact of $25-\mathrm{OH}$ vitamin $\mathrm{D}$ on vascular function, $\mathrm{cBP}$, and the BPR to exercise in athletes are needed.

Overall, the clinical importance of the BPR to exercise and maximum systolic BP is obvious, as it has been shown that a high BPR to exercise predicts future development of hypertension in young athletes (Caselli et al. 2019) as well as the normal population (Tzemos et al. 2015; Percuku et al. 2019; Schultz et al. 2015). Athletes are more frequently exposed to exercise-induced high BP than sedentary individuals, and exercise testing is frequently performed in the cardiovascular evaluation of competitive athletes (Hedman et al. 2019b). Therefore, reliable cut-off values have to be established and, given the workload-dependent BPR to exercise, a workload-adjusted approach instead of using absolute cut-off values might be a good strategy for identifying athletes with an exaggerated BPR (Hedman et al. 2019a). Thus far, insufficient $25-\mathrm{OH}$ vitamin D levels do not appear to be 
a risk factor for an exaggerated BPR to a maximum exercise test in professional male indoor athletes.

\section{Limitations}

Our study has a few noteworthy limitations. The number of participants limited its power to uncover potential correlations between 25-OH vitamin D status and markers of cardiac and vascular function other than brachial BP and the BPR to a maximum exercise test. The focus on professional indoor handball and ice hockey players may limit extrapolation of the results to other sport disciplines; however, as these team sports expose athletes to the haemodynamic stress of frequent interval sprints, they are representative of other sports with a high dynamic component $(>75 \%$ VO2max) and a moderate static component (10-20\%) (Levine et al. 2015). A further limitation is our exclusive focus on male athletes, which precludes the extrapolation of our results to female athletes. We are currently addressing all three issues by extending our research to include larger numbers of professional male and female athletes from various sports disciplines.

\section{Conclusion}

We have shown for the first time that professional male handball and ice hockey players with sufficient $25-\mathrm{OH}$ vitamin D levels display a higher maximum systolic BP during a maximum exercise test than do athletes with insufficient $25-\mathrm{OH}$ vitamin D levels. This difference was an expression of a significantly higher MPO in vitamin D-sufficient athletes, highlighting the impact of vitamin D on physical performance of these athletes. Thus, the BPR between athletes with sufficient $25-\mathrm{OH}$ vitamin D levels compared to those with insufficient levels was not different. Further, in both groups of athletes, the BPR to a maximum exercise did not exceed the currently proposed thresholds for athletes.

We suggest that highly- trained athletic populations present a unique opportunity to address the modifying effects of cardiorespiratory fitness on the association of 25-OH vitamin D with cardiovascular risk markers. Our results may serve to stimulate future investigations into the correlation of vitamin D with parameters of vascular function and central haemodynamic parameters.

Acknowledgments Open Access funding provided by Projekt DEAL. The authors would like to thank Elizabeth A. Martinson, $\mathrm{PhD}$, for her assistance in manuscript preparation and language editing.

Author contributions $\mathrm{PB}, \mathrm{AM}, \mathrm{CH}, \mathrm{OD}, \mathrm{HN}$ contributed to the conception and design of the study. PB, AM, LK, TB, CH contributed to the acquisition, analysis, or interpretation of data for the work. PB and AM drafted the manuscript. PB, AM, LK, TB, OD, HN critically revised the manuscript. All gave final approval and agree to be accountable for all aspects of work ensuring integrity and accuracy.

\section{Compliance with ethical standards}

Conflict of interest The authors declare no potential conflicts of interest.

Open Access This article is licensed under a Creative Commons Attribution 4.0 International License, which permits use, sharing, adaptation, distribution and reproduction in any medium or format, as long as you give appropriate credit to the original author(s) and the source, provide a link to the Creative Commons licence, and indicate if changes were made. The images or other third party material in this article are included in the article's Creative Commons licence, unless indicated otherwise in a credit line to the material. If material is not included in the article's Creative Commons licence and your intended use is not permitted by statutory regulation or exceeds the permitted use, you will need to obtain permission directly from the copyright holder. To view a copy of this licence, visit http://creativecommons.org/licenses/by/4.0/.

\section{References}

Al Mheid I, Patel R, Murrow J, Morris A, Rahman A, Fike L, Kavtaradze N, Uphoff I, Hooper C, Tangpricha V, Alexander RW, Brigham K, Quyyumi AA (2011) Vitamin D status is associated with arterial stiffness and vascular dysfunction in healthy humans. J Am Coll Cardiol 58(2):186-192. https://doi. org/10.1016/j.jacc.2011.02.051

Allison RJ, Close GL, Farooq A, Riding NR, Salah O, Hamilton B, Wilson MG (2015) Severely vitamin D-deficient athletes present smaller hearts than sufficient athletes. Eur J Prev Cardiol 22(4):535-542. https://doi.org/10.1177/2047487313518473

Anderson JL, May HT, Horne BD, Bair TL, Hall NL, Carlquist JF, Lappe DL, Muhlestein JB, Intermountain Heart Collaborative Study G (2010) Relation of vitamin D deficiency to cardiovascular risk factors, disease status, and incident events in a general healthcare population. Am J Cardiol 106(7):963-968. https:// doi.org/10.1016/j.amjcard.2010.05.027

Babur Guler G, Guler E, Hatipoglu S, Gunes HM, Gecmen C, Demir GG, Barutcu I (2016) Assessment of 25-OH vitamin D levels and abnormal blood pressure response in female patients with cardiac syndrome X. Anatol J Cardiol 16(12):961-966. https:// doi.org/10.14744/AnatolJCardiol.2016.6862

Bauer P, Henni S, Dorr O, Bauer T, Hamm CW, Most A (2018) High prevalence of vitamin D insufficiency in professional handball athletes. Phys Sportsmed. https://doi.org/10.1080/00913 847.2018.1520055

Bauer P, Kraushaar L, Holscher S, Tajmiri-Gondai S, Dorr O, Nef H, Hamm C, Most A (2019) Elite athletes as research model: vitamin D insufficiency associates with elevated central blood pressure in professional handball athletes. Eur J Appl Physiol. https://doi.org/10.1007/s00421-019-04210-w

Berge HM, Isern CB, Berge E (2015) Blood pressure and hypertension in athletes: a systematic review. Br J Sports Med 49(11):716-723. https://doi.org/10.1136/bjsports-2014-093976

Cannell JJ, Hollis BW, Sorenson MB, Taft TN, Anderson JJ (2009) Athletic performance and vitamin D. Med Sci Sports Exerc 41(5):1102-1110. https://doi.org/10.1249/MSS.0b013e3181 $930 \mathrm{c} 2 \mathrm{~b}$

Caselli S, Serdoz A, Mango F, Lemme E, Vaquer Segui A, Milan A, Attenhofer Jost C, Schmied C, Spataro A, Pelliccia A (2019) 
High blood pressure response to exercise predicts future development of hypertension in young athletes. Eur Heart J 40(1):6268. https://doi.org/10.1093/eurheartj/ehy810

Caselli S, Vaquer Segui A, Quattrini F, Di Gacinto B, Milan A, Assorgi R, Verdile L, Spataro A, Pelliccia A (2016) Upper normal values of blood pressure response to exercise in Olympic athletes. Am Heart J 177:120-128. https://doi.org/10.1016/j. ahj.2016.04.020

Cheng HM, Chuang SY, Sung SH, Yu WC, Pearson A, Lakatta EG, Pan WH, Chen CH (2013) Derivation and validation of diagnostic thresholds for central blood pressure measurements based on long-term cardiovascular risks. J Am Coll Cardiol 62(19):1780-1787. https://doi.org/10.1016/j.jacc.2013.06.029

Christakos S, Hewison M, Gardner DG, Wagner CL, Sergeev IN, Rutten E, Pittas AG, Boland R, Ferrucci L, Bikle DD (2013) Vitamin D: beyond bone. Ann N Y Acad Sci 1287:45-58. https ://doi.org/10.1111/nyas.12129

Currie KD, Floras JS, La Gerche A, Goodman JM (2018) Exercise blood pressure guidelines: time to re-evaluate what is normal and exaggerated? Sports Med 48(8):1763-1771. https://doi. org/10.1007/s40279-018-0900-x

Du Bois D, Du Bois EF (1989) A formula to estimate the approximate surface area if height and weight be known 1916. Nutrition 5(5):303-311 (discussion 312-303)

Fan F, Qi L, Jia J, Xu X, Liu Y, Yang Y, Qin X, Li J, Li H, Zhang Y, Huo Y (2016) Noninvasive central systolic blood pressure is more strongly related to kidney function decline than peripheral systolic blood pressure in a Chinese community-based population. Hypertension 67(6):1166-1172. https://doi.org/10.1161/HYPER TENSIONAHA.115.07019

Forman JP, Williams JS, Fisher ND (2010) Plasma 25-hydroxyvitamin $\mathrm{D}$ and regulation of the renin-angiotensin system in humans. Hypertension 55(5):1283-1288. https://doi.org/10.1161/HYPER TENSIONAHA.109.148619

Gupta MP, Polena S, Coplan N, Panagopoulos G, Dhingra C, Myers J, Froelicher V (2007) Prognostic significance of systolic blood pressure increases in men during exercise stress testing. Am J Cardiol 100(11):1609-1613. https://doi.org/10.1016/j.amjca rd.2007.06.070

Hamilton B, Whiteley R, Farooq A, Chalabi H (2014) Vitamin D concentration in 342 professional football players and association with lower limb isokinetic function. J Sci Med Sport 17(1):139_ 143. https://doi.org/10.1016/j.jsams.2013.03.006

Harriss DJ, Macsween A, Atkinson G (2017) Standards for ethics in sport and exercise science research: 2018 update. Int J Sports Med 38(14):1126-1131. https://doi.org/10.1055/s-0043-124001

He CS, Aw Yong XH, Walsh NP, Gleeson M (2016) Is there an optimal vitamin D status for immunity in athletes and military personnel? Exerc Immunol Rev 22:42-64

Hedman K, Cauwenberghs N, Christle JW, Kuznetsova T, Haddad F, Myers J (2019a) Workload-indexed blood pressure response is superior to peak systolic blood pressure in predicting all-cause mortality. Eur J Prev Cardiol. https://doi.org/10.1177/2047487319 877268

Hedman K, Moneghetti KJ, Christle JW, Bagherzadeh SP, Amsallem M, Ashley E, Froelicher V, Haddad F (2019b) Blood pressure in athletic preparticipation evaluation and the implication for cardiac remodelling. Heart 105(16):1223-1230. https://doi.org/10.1136/ heartjnl-2019-314815

Herbert A, Cruickshank JK, Laurent S, Boutouyrie P, Reference Values for Arterial Measurements C (2014) Establishing reference values for central blood pressure and its amplification in a general healthy population and according to cardiovascular risk factors. Eur Heart J 35(44):3122-3133. https://doi.org/10.1093/eurheartj/ehu293
Hodson B, Norton GR, Booysen HL, Sibiya MJ, Raymond A, Maseko MJ, Majane OH, Libhaber E, Sareli P, Woodiwiss AJ (2016) Brachial pressure control fails to account for most distending pressure-independent, age-related aortic hemodynamic changes in adults. Am J Hypertens 29(5):605-613. https://doi.org/10.1093/ ajh/hpv140

Holick MF, Binkley NC, Bischoff-Ferrari HA, Gordon CM, Hanley DA, Heaney RP, Murad MH, Weaver CM (2012) Guidelines for preventing and treating vitamin D deficiency and insufficiency revisited. J Clin Endocrinol Metab 97(4):1153-1158. https://doi. org/10.1210/jc.2011-2601

Holick MF, Binkley NC, Bischoff-Ferrari HA, Gordon CM, Hanley DA, Heaney RP, Murad MH, Weaver CM, Endocrine S (2011) Evaluation, treatment, and prevention of vitamin D deficiency: an endocrine society clinical practice guideline. J Clin Endocrinol Metab 96(7):1911-1930. https://doi.org/10.1210/jc.2011-0385

Holmqvist L, Mortensen L, Kanckos C, Ljungman C, Mehlig K, Manhem K (2012) Exercise blood pressure and the risk of future hypertension. J Hum Hypertens 26(12):691-695. https://doi. org/10.1038/jhh.2011.99

Kim D, Ha JW (2016) Hypertensive response to exercise: mechanisms and clinical implication. Clin Hypertens 22:17. https://doi. org/10.1186/s40885-016-0052-y

Krzywanski J, Mikulski T, Krysztofiak H, Mlynczak M, Gaczynska E, Ziemba A (2016) Seasonal vitamin D status in Polish elite athletes in relation to sun exposure and oral supplementation. PLoS ONE 11(10):e0164395. https://doi.org/10.1371/journal.pone.0164395

Ksiazek A, Zagrodna A, Dziubek W, Pietraszewski B, Ochmann B, Slowinska-Lisowska M (2016) 25(OH)D3 levels relative to muscle strength and maximum oxygen uptake in athletes. J Hum Kinet 50:71-77. https://doi.org/10.1515/hukin-2015-0144

Kunutsor SK, Apekey TA, Steur M (2013) Vitamin D and risk of future hypertension: meta-analysis of 283,537 participants. Eur J Epidemiol 28(3):205-221. https://doi.org/10.1007/s10654-013-9790-2

Levine BD, Baggish AL, Kovacs RJ, Link MS, Maron MS, Mitchell $\mathrm{JH}$, American Heart Association E, Arrhythmias Committee of Council on Clinical Cardiology CoCDiYCoC, Stroke Nursing CoFG, Translational B, American College of C (2015) Eligibility and disqualification recommendations for competitive athletes with cardiovascular abnormalities: task force 1: classification of sports: dynamic, static, and impact: a scientific statement from the American heart association and American college of cardiology. Circulation 132(22):e262-266. https://doi.org/10.1161/CIR.00000 00000000237

Lewis GD, Gona P, Larson MG, Plehn JF, Benjamin EJ, O'Donnell CJ, Levy D, Vasan RS, Wang TJ (2008) Exercise blood pressure and the risk of incident cardiovascular disease (from the Framingham Heart Study). Am J Cardiol 101(11):1614-1620. https://doi. org/10.1016/j.amjcard.2008.01.046

Mancia G, Fagard R, Narkiewicz K, Redon J, Zanchetti A, Bohm M, Christiaens T, Cifkova R, De Backer G, Dominiczak A, Galderisi M, Grobbee DE, Jaarsma T, Kirchhof P, Kjeldsen SE, Laurent S, Manolis AJ, Nilsson PM, Ruilope LM, Schmieder RE, Sirnes PA, Sleight P, Viigimaa M, Waeber B, Zannad F, Redon J, Dominiczak A, Narkiewicz K, Nilsson PM, Burnier M, Viigimaa M, Ambrosioni E, Caufield M, Coca A, Olsen MH, Schmieder RE, Tsioufis C, van de Borne P, Zamorano JL, Achenbach S, Baumgartner H, Bax JJ, Bueno H, Dean V, Deaton C, Erol C, Fagard R, Ferrari R, Hasdai D, Hoes AW, Kirchhof P, Knuuti J, Kolh P, Lancellotti P, Linhart A, Nihoyannopoulos P, Piepoli MF, Ponikowski P, Sirnes PA, Tamargo JL, Tendera M, Torbicki A, Wijns W, Windecker S, Clement DL, Coca A, Gillebert TC, Tendera M, Rosei EA, Ambrosioni E, Anker SD, Bauersachs J, Hitij JB, Caulfield M, De Buyzere M, De Geest S, Derumeaux GA, Erdine S, Farsang C, Funck-Brentano C, Gerc V, Germano G, Gielen S, 
Haller H, Hoes AW, Jordan J, Kahan T, Komajda M, Lovic D, Mahrholdt H, Olsen MH, Ostergren J, Parati G, Perk J, Polonia J, Popescu BA, Reiner Z, Ryden L, Sirenko Y, Stanton A, StruijkerBoudier H, Tsioufis C, van de Borne P, Vlachopoulos C, Volpe M, Wood DA (2013) $2013 \mathrm{ESH} / \mathrm{ESC}$ guidelines for the management of arterial hypertension: the task force for the management of arterial hypertension of the European society of hypertension (ESH) and of the European society of cardiology (ESC). Eur Heart J 34(28):2159-2219. https://doi.org/10.1093/eurheartj/eht151

Maroon JC, Mathyssek CM, Bost JW, Amos A, Winkelman R, Yates AP, Duca MA, Norwig JA (2015) Vitamin D profile in national football league players. Am J Sports Med 43(5):1241-1245. https ://doi.org/10.1177/0363546514567297

Mehran N, Schulz BM, Neri BR, Robertson WJ, Limpisvasti O (2016) Prevalence of vitamin D insufficiency in professional hockey players. Orthop J Sports Med 4(12):2325967116677512. https://doi. org/10.1177/2325967116677512

Morton JP, Iqbal Z, Drust B, Burgess D, Close GL, Brukner PD (2012) Seasonal variation in vitamin $\mathrm{D}$ status in professional soccer players of the english premier league. Appl Physiol Nutr Metab 37(4):798-802. https://doi.org/10.1139/h2012-037

Norman AW (2008) From vitamin D to hormone D: fundamentals of the vitamin D endocrine system essential for good health. Am J Clin Nutr 88(2):491S-499S. https://doi.org/10.1093/ ajen/88.2.491S

Owens DJ, Allison R, Close GL (2018) Vitamin D and the athlete: current perspectives and new challenges. Sports Med 48(Suppl 1):3-16. https://doi.org/10.1007/s40279-017-0841-9

Owens DJ, Fraser WD, Close GL (2015) Vitamin D and the athlete: emerging insights. Eur J Sport Sci 15(1):73-84. https://doi. org/10.1080/17461391.2014.944223

Percuku L, Bajraktari G, Jashari H, Bytyci I, Ibrahimi P, Henein MY (2019) The exaggerated systolic hypertensive response to exercise associates cardiovascular events: a systematic review and meta-analysis. Pol Arch Intern Med. https://doi.org/10.20452/ pamw. 15007

Pludowski P, Karczmarewicz E, Bayer M, Carter G, Chlebna-Sokol D, Czech-Kowalska J, Debski R, Decsi T, Dobrzanska A, Franek E, Gluszko P, Grant WB, Holick MF, Yankovskaya L, Konstantynowicz J, Ksiazyk JB, Ksiezopolska-Orlowska K, Lewinski A, Litwin M, Lohner S, Lorenc RS, Lukaszkiewicz J, MarcinowskaSuchowierska E, Milewicz A, Misiorowski W, Nowicki M, Povoroznyuk V, Rozentryt P, Rudenka E, Shoenfeld Y, Socha P, Solnica B, Szalecki M, Talalaj M, Varbiro S, Zmijewski MA (2013) Practical guidelines for the supplementation of vitamin $\mathrm{D}$ and the treatment of deficits in Central Europe-recommended vitamin $\mathrm{D}$ intakes in the general population and groups at risk of vitamin D deficiency. Endokrynol Pol 64(4):319-327

Pressler A, Jahnig A, Halle M, Haller B (2018) Blood pressure response to maximal dynamic exercise testing in an athletic population. $\mathrm{J}$ Hypertens 36(9):1803-1809. https://doi.org/10.1097/HJH.00000 00000001791

Priemel M, von Domarus C, Klatte TO, Kessler S, Schlie J, Meier S, Proksch N, Pastor F, Netter C, Streichert T, Puschel K, Amling M (2010) Bone mineralization defects and vitamin D deficiency: histomorphometric analysis of iliac crest bone biopsies and circulating 25-hydroxyvitamin D in 675 patients. J Bone Miner Res 25(2):305-312. https://doi.org/10.1359/jbmr.090728

Roman MJ, Devereux RB, Kizer JR, Lee ET, Galloway JM, Ali T, Umans JG, Howard BV (2007) Central pressure more strongly relates to vascular disease and outcome than does brachial pressure: the strong heart study. Hypertension 50(1):197-203. https:// doi.org/10.1161/HYPERTENSIONAHA.107.089078

Schultz MG, Otahal P, Cleland VJ, Blizzard L, Marwick TH, Sharman JE (2013) Exercise-induced hypertension, cardiovascular events, and mortality in patients undergoing exercise stress testing: a systematic review and meta-analysis. Am J Hypertens 26(3):357366. https://doi.org/10.1093/ajh/hps053

Schultz MG, Otahal P, Picone DS, Sharman JE (2015) Clinical relevance of exaggerated exercise blood pressure. J Am Coll Cardiol 66(16):1843-1845. https://doi.org/10.1016/j.jacc.2015.08.015

Somjen D, Weisman Y, Kohen F, Gayer B, Limor R, Sharon O, Jaccard N, Knoll E, Stern N (2005) 25-hydroxyvitamin D3-1alphahydroxylase is expressed in human vascular smooth muscle cells and is upregulated by parathyroid hormone and estrogenic compounds. Circulation 111(13):1666-1671. https://doi. org/10.1161/01.CIR.0000160353.27927.70

Stephen Hedley J, Phelan D (2017) Athletes and the aorta: normal adaptations and the diagnosis and management of pathology. Curr Treat Options Cardiovasc Med 19(11):88. https://doi.org/10.1007/ s11936-017-0586-7

Tahir E, Starekova J, Muellerleile K, von Stritzky A, Munch J, Avanesov M, Weinrich JM, Stehning C, Bohnen S, Radunski UK, Freiwald E, Blankenberg S, Adam G, Pressler A, Patten M, Lund GK (2018) Myocardial fibrosis in competitive triathletes detected by contrast-enhanced CMR correlates with exercise-induced hypertension and competition history. JACC Cardiovasc Imaging 11(9):1260-1270. https://doi.org/10.1016/j.jcmg.2017.09.016

Tarcin O, Yavuz DG, Ozben B, Telli A, Ogunc AV, Yuksel M, Toprak A, Yazici D, Sancak S, Deyneli O, Akalin S (2009) Effect of vitamin $\mathrm{D}$ deficiency and replacement on endothelial function in asymptomatic subjects. J Clin Endocrinol Metab 94(10):40234030. https://doi.org/10.1210/jc.2008-1212

Thijssen DH, Carter SE, Green DJ (2016) Arterial structure and function in vascular ageing: are you as old as your arteries? J Physiol 594(8):2275-2284. https://doi.org/10.1113/JP270597

Tzemos N, Lim PO, MacDonald TM (2009) Exercise blood pressure and endothelial dysfunction in hypertension. Int J Clin Pract 63(2):202-206. https://doi.org/10.1111/j.1742-1241.2008.01922.x

Tzemos N, Lim PO, Mackenzie IS, MacDonald TM (2015) Exaggerated exercise blood pressure response and future cardiovascular disease. J Clin Hypertens (Greenwich) 17(11):837-844. https:// doi.org/10.1111/jch.12629

Vimaleswaran KS, Cavadino A, Berry DJ, LifeLines Cohort Study i, Jorde R, Dieffenbach AK, Lu C, Alves AC, Heerspink HJ, Tikkanen E, Eriksson J, Wong A, Mangino M, Jablonski KA, Nolte IM, Houston DK, Ahluwalia TS, van der Most PJ, Pasko D, Zgaga L, Thiering E, Vitart V, Fraser RM, Huffman JE, de Boer RA, Schottker B, Saum KU, McCarthy MI, Dupuis J, Herzig KH, Sebert S, Pouta A, Laitinen J, Kleber ME, Navis G, Lorentzon M, Jameson K, Arden N, Cooper JA, Acharya J, Hardy R, Raitakari O, Ripatti S, Billings LK, Lahti J, Osmond C, Penninx BW, Rejnmark L, Lohman KK, Paternoster L, Stolk RP, Hernandez DG, Byberg L, Hagstrom E, Melhus H, Ingelsson E, Mellstrom D, Ljunggren O, Tzoulaki I, McLachlan S, Theodoratou E, Tiesler CM, Jula A, Navarro P, Wright AF, Polasek O, International Consortium for Blood P, Cohorts for H, Aging Research in Genomic Epidemiology c, Global Blood Pressure Genetics c, Caroline H, Wilson JF, Rudan I, Salomaa V, Heinrich J, Campbell H, Price JF, Karlsson M, Lind L, Michaelsson K, Bandinelli S, Frayling TM, Hartman CA, Sorensen TI, Kritchevsky SB, Langdahl BL, Eriksson JG, Florez JC, Spector TD, Lehtimaki T, Kuh D, Humphries SE, Cooper C, Ohlsson C, Marz W, de Borst MH, Kumari M, Kivimaki M, Wang TJ, Power C, Brenner H, Grimnes G, van der Harst P, Snieder H, Hingorani AD, Pilz S, Whittaker JC, Jarvelin MR, Hypponen E (2014) Association of vitamin D status with arterial blood pressure and hypertension risk: a mendelian randomisation study. Lancet Diabetes Endocrinol 2(9):719-729. https ://doi.org/10.1016/S2213-8587(14)70113-5

Wang TJ (2016) Vitamin D and cardiovascular disease. Annu Rev Med 67:261-272. https://doi.org/10.1146/annurev-med-051214-02514 6 
Weiss SA, Blumenthal RS, Sharrett AR, Redberg RF, Mora S (2010) Exercise blood pressure and future cardiovascular death in asymptomatic individuals. Circulation 121(19):2109-2116. https://doi. org/10.1161/CIRCULATIONAHA.109.895292

Wilkinson IB, Franklin SS, Hall IR, Tyrrell S, Cockcroft JR (2001) Pressure amplification explains why pulse pressure is unrelated to risk in young subjects. Hypertension 38(6):1461-1466

Williams B, Lacy PS, Thom SM, Cruickshank K, Stanton A, Collier D, Hughes AD, Thurston H, O'Rourke M, Investigators C, Anglo-Scandinavian Cardiac Outcomes Trial I, Committee CS, Writing C (2006) Differential impact of blood pressure-lowering drugs on central aortic pressure and clinical outcomes: principal results of the conduit artery function evaluation (CAFE) study. Circulation 113(9):1213-1225. https://doi.org/10.1161/CIRCU LATIONAHA.105.595496

Williams B, Mancia G, Spiering W, Agabiti Rosei E, Azizi M, Burnier M, Clement DL, Coca A, de Simone G, Dominiczak A, Kahan T, Mahfoud F, Redon J, Ruilope L, Zanchetti A, Kerins M, Kjeldsen SE, Kreutz R, Laurent S, Lip GYH, McManus R, Narkiewicz K, Ruschitzka F, Schmieder RE, Shlyakhto E, Tsioufis C, Aboyans V, Desormais I, Group ESCSD (2018) 2018 ESC/ESH guidelines for the management of arterial hypertension. Eur Heart J 39(33):3021-3104. https://doi.org/10.1093/eurheartj/ehy339

Zaleski A, Taylor B, Armstrong B, Puglisi M, Clarkson P, Chipkin S, White CM, Thompson PD, Pescatello LS (2019) Associations of 25-hydroxyvitamin D With the blood pressure response to maximal exercise among healthy adults. Int J Sport Nutr Exerc Metab 29(3):303-308. https://doi.org/10.1123/ijsnem.2017-0424

Zorzi A, Perazzolo Marra M, Rigato I, De Lazzari M, Susana A, Niero A, Pilichou K, Migliore F, Rizzo S, Giorgi B, De Conti G, Sarto P, Serratosa L, Patrizi G, De Maria E, Pelliccia A, Basso C, Schiavon M, Bauce B, Iliceto S, Thiene G, Corrado D (2016) Nonischemic left ventricular scar as a substrate of life-threatening ventricular arrhythmias and sudden cardiac death in competitive athletes. Circ Arrhythm Electrophysiol 9:7. https://doi.org/10.1161/CIRCE P.116.004229

Publisher's Note Springer Nature remains neutral with regard to jurisdictional claims in published maps and institutional affiliations. 